\title{
東京都と神奈川県における農家の移築棟数と地域性について \\ ABOUT THE QUANTITY AND LOCALITY OF REMOVING AND RECONSTRUCTION OF THE FOLK HOUSE IN THE TOKYO AND KANAGAWA PREFECTURE
}

\author{
平山充男* \\ IkUo HIRA YAMA
}

The purpose of this study is to reveal the status of folk houses that have been relocated from their original sites. In this paper, the quantity and regional characteristics of moved residences in Tokyo and Kanagawa Prefectures have been clarified.It became clear that of the 2,259 folk houses investigated in the given area, 284 structures had been dismantled, moved, and reconstructed, constituting a ratio of at least $13 \%$.

Keywords : Folk house, Removing and reconstruction, Report 民家、移築、報告書

\section{1. はじめに}

民家については従来、調查等の知見を通して比較的多くの移筑 例が単発的にではあるが報告されている。しかし、その実数や実 態は不明の部分が多く、移築の理由についても未詳の事柄が多い。

民家移築の既往研究では、史料等を通して富山県佐伯家におけ る移筑の実態を明らかにした宮沢智士氏のもの1や、移築が高持 農民の生活困窮による家屋敷を売買と強く関係するとした草野和 夫2氏の研究が挙げられる。一方、民家の移筑はそこに新築的な 意義が込められることなどを筆者らは既に指摘している3。

ところが従来の研究では民家の移築についてその実数を実証的 に明らかにしたものはない。また、民家の移築は草野氏が指摘す るように生活困窮の結果、改築予定者や分家予定者へ売買される 場合も少なからず存在するが、そのような例が全てではないよう である。このように民家の移築については、未だ央数やその動機 などは解明されるに至っておらず、更にこれがどのような理由で 成立・展開したのかも明らかではない。そこで本研究では民家の 移築におけるこれらつ問題を実資料に即し、実態的に明らかにす ることを目的とするが、本稿においてはこの内、移築民家の数量 を把握することを第一の目的に、加えて地域的な差異の有無を見 るものである。なお、民家の移築は主屋以外の土蔵、納屋、長屋 門などの付属屋等でも多々見られる゙が、本稿ではこの内、農家 の主屋に限り考察を進める。

\section{2. 対象の設定と移築民家の定義}

\section{・調査対象の設定}

民家の移築はこれまで各々の民家調査等を通して数々報告され ているが、実数は明らかでない。その中で宮本常一氏は

昔は村の家の一割や二割はそうした（移築を受けた : 著者 注）家ではなかったかといわれている5

としている。この数が何によるものか根拠は示されないが、実際 にはどれ程の数の民家が移築を受けたのであろうか。

筆者らが実施した東京都稲城市の民家調査では表 1 に挙げたよ うに、調查した主屋建物 21 棟の内 6 棟（29\%、以下、本文中で は小数点以下を四捨五入する。）が移築に関係する民家であった6。 またこれらとは別に、市域からは隣接の府中市へ 2 棟、調布市 へ1 1 棟 ${ }^{8}$ 民家が移築されていたことが周辺地区における民家調 査によって確認された。このように稲城市の調查においてはかな りの数量の民家が移築を受けたものであることを実感した。

移築の問題を考える発端は稲城市の民家調査であったが、実際 にはどれ程の数量に及ふ移築民家が存在するのか示すため、稲城 市における数値をもって実情とすることには躊躇があった。狭い 地域における調査では特殊な事情や、地域固有の条件により移築 の棟数に増減の生じる可能性が考えられたからである。一方、全 国を対象とする民家の把握には国指定重要文化財や国などを中心 とする緊急調査の結果を用いる方法も考えられた。ところで、民 家緊急調查では “規模・古さ・保存程度などの点ですぐれるもの 
を選んで”9調査のなされる傾向がある。しかし、移築民家では 移築に伴い改造や変更の行われることが多く、前述のように移築 に新築的な意義の込められることも多いため、移築民家が調査対 象から漏れる可能性が高いと考えられた。実際、緊急調査などに 基づいて指定の進んだ国指定重要文化財の民家 332 棟において 移築民家は 17 棟で、全体に占める割合は $5 \%$ 、農家に限っても 258 棟の内 15 棟、6\% ${ }^{10}$ に過ぎなかった。

そのため移築民家の数量を考える場合、ある程度広い地域にお いて民家の実態を知ることのできる組織的な調査の実施されてい る必要性を感じた11。そこで本稿では一定の連続的な広がりを持 ち、かつ高密度に民家調查が実施されている地域として、前述の 稲城市も含まれる東京都及び神奈川県全域を対象に、都・県に加 え、各自治体による民家調查などを総合的に比較検討し、民家の 調查棟数とこれに占める移築民家の棟数を見ることとした。

\section{・移筮民家の定義}

建築基㔼法に「移築」の定義はないが、これに近いものに「移 動」の語が第 2 条にある ${ }^{12}$ 。同法における「移動」とは同一敷地 内で建物を動かすことを示すが、本稿において移筑とは敷地の同 一を問わず、建物を元の位置から動かした全てを含むものとした。 つまり、同一敷地内における曳家等による移動や、異なる敷地へ 建物を移設することを含め本稿では移築とした。また、各報告書 筆者の考察から「移筑の可能性がある」などと指摘されるものは 移築と見なしたが、「古材の利用が認められる」とだけされるも のは旧・古材利用のみの可能性もあり、移築とは見なさなかった。

なお、主に戦後、歴史的な民家を行政等が中心に建物を移築し、 保存することが広く行われた。これらは重要文化財に指定された 民家建築主屋でも 332 棟の内 79 棟、24\%、農家に限れば 258 棟の内 72 棟、28\%を占める13。本稿ではこのように保存を目的 に戦後に移筑された民家は「保存移築」とし、上で定義した移筑 の棟数に数えなかった。但し、中には保存移筑される以前、既に 移築を受けた民家があり、これらは移築された民家と見なした。 また、表題の「農家」とは第 1 次産業を生業とするものの総称と し、分類は利用した以下に示した報告書等における執筆者の判断 に委ねた。

\section{3、用いた報告書や書籍}

本稿では対象地域を東京都、神奈川県全域とし、移築民家の 実態を知るために以下の報告書、書籍（以下、「報告書等」と称 する。考察に用い、それらを参考文献の欄に記した。

\section{・東京都における民家調查の報告書等}

東京都では全域を網羅した民家調查の報告書は刊行されていな いが、昭和 29(1954)年以後、都教育厅によって地域を分割して 実施された文化財調查の一環として民家調査が行なわれたため、 この調查報告書を先ず考察に用いた ${ }^{14}$ 。次いで多くの自治体で市 史類 ${ }^{15}$ が刊行され、その中で民家調査の報告があり、これらも通 読した。加えて区部では板橋区、大田区、北区（一部地区）、世 田谷区、練馬区（50 音順、以下同様。）の4区、三多摩地方では 昭島市、稲城市、青梅市、国立市、国分寺市、狛江市、立川市 (砂 川地区)、多摩市、調布市、日野市、府中市、福生市、町田市、 三鷹市の14市において民家建築調査の報告書が刊行されており、
これらも用いた。併せて単体の民家建築についての調査報告書、 保存移築等に伴う工事報告書も可能な限り目を通した。そして、 都全域及び福生市、武蔵村山市などでは民俗系調査の一環として 民家建築の調查があり、これらも考察に用いた。そして、以上の 報告書等を判読の上、各棟の判別がつき、解説に建築年代の記載 があり移築か否かの判断ができるものを棟数として数えた。なお、 各報告書等の資料間では少なからぬ重複があり、これらの校定を 行なった上、重複を省いて調查民家、移築民家の棟数を数えた 16 。

\section{・神奈川県における民家調査の報告書等}

神奈川県でも国補助金による民家緊急調査は行なわれなかった が、戦後、いち早く県域において民家調査が実施され 17 、地域ご との報告書18や野帳集19が刊行されたため、先ずこれらを考察に 利用した。次いで同県でも多くの自治体で市史類が刊行されてお り、可能な限りこれらに当つた。加えて県下の厚木市、相模原市、 座間市、逗子市、秦野市、藤沢市、大和市の 7 市において民家調 査に基づく報告書が刊行されるとともに、単体でも多数の報告書 があり、これらに可能な限り目を通した。また、綾瀬市、川崎市、 平塚市などでは民俗系調査の一環として民家調査が実施されてお り、これらも各棟の判別がつき、解説から移筑か否かの判断がで きるものに限り、調查棟数、移筑棟数として数えた。なお、神奈 川県においても報告書等の間における資料の重複を校定した20。

\section{4 対象地域における調査民家と移策民家の棟数}

上で述べた報告書等から、対象地域における調査民家と移築民 家の棟数を求めた結果は以下の通りである。

東京都 23 区内では 12 区において 268 棟の調査民家があり、 その内 24 棟、9\%が移築民家であった。多摩地方では同じく 30 市町村で 587 棟の調査民家があり、68 棟、12\%が移築民家、島 嶼部では 6 町村で 25 棟の調查民家があり、内 2 棟の $8 \%$ が移築 民家であった。以上を合計すると、東京都内では 880 棟の調查 民家の内 94 棟、11\%が移筑民家であることが判明した。

また、神奈川県下では横浜市で 105 棟の調查民家があり、そ の内 10 棟の $10 \%$ が移築民家、川崎市では 45 棟の調査民家中 5 棟、11\%が移築民家であった。そしてこれ以外の県下 34 市町村 では 1229 棟の調査民家があり 175 棟、14\%が移築民家であり、 これらを合計すると神奈川県では 1,379 棟の調查民家中 190 棟、 14\%が移筑民家であることが判明した。

以上のように各地域間ではやや偏りも見られるが、いずれの地 域でも 1 割程度の数に昇る移築民家が存在し、地域間における差 異を考慮せずに合計すると東京都、神奈川県の全域では 2,259 棟の調査民家の報告があり、この内少なくとも ${ }^{21} 284$ 棟、13\%、 約 8 棟に 1 棟の民家が移築を受けたもので、先に挙げた宮本の 数字も実態にほぼ即したものと考えることができた。

ところで調査の方法自体が移築民家の数量を左右する要因の 1 つであることが指摘できる。例えば宮本による府中市域の民家調 査報告書である『府中市史近代編資料集第 1 集一府中市の現存草 莫民家調査集一』22を見ると、他の報告書等より判明する移築民 家の記述がない。他市に比べて少ない割合である同市における移 築民家もこれより多い可能性が高い。なお、民俗系の調査におい ては住宅の建築年代や来歴自体の調査が調査主旨に必ずしも反映 
表 1 東京都・神奈川県における眮查民家と䅂築民家の棟数

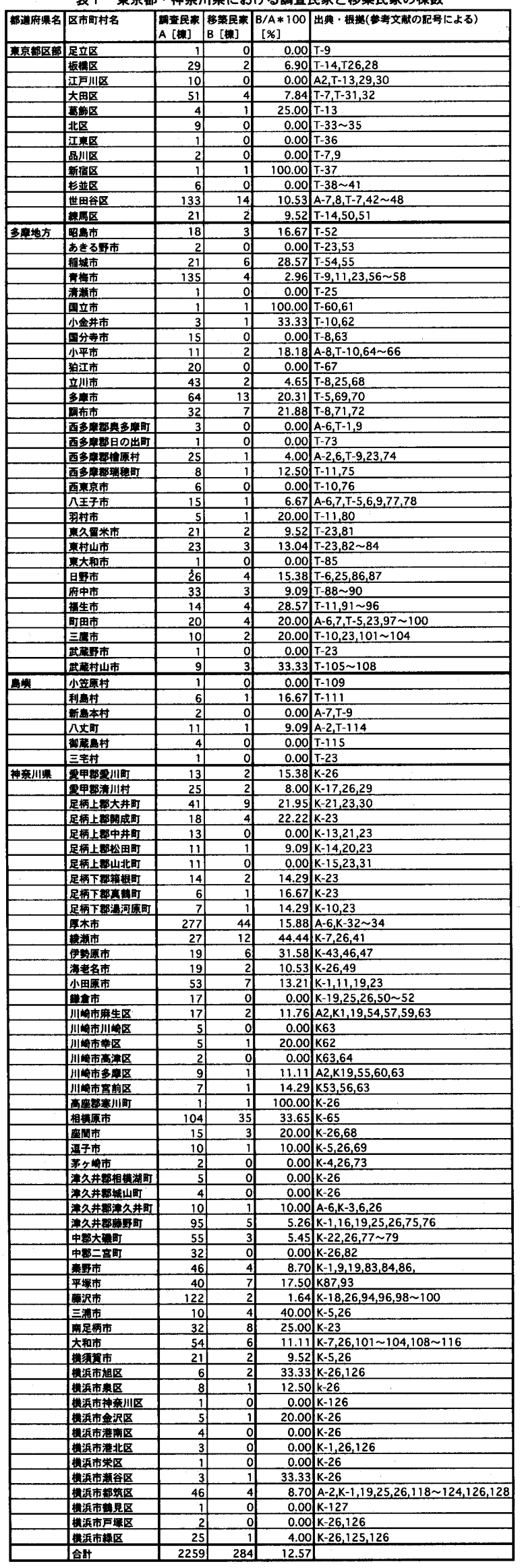

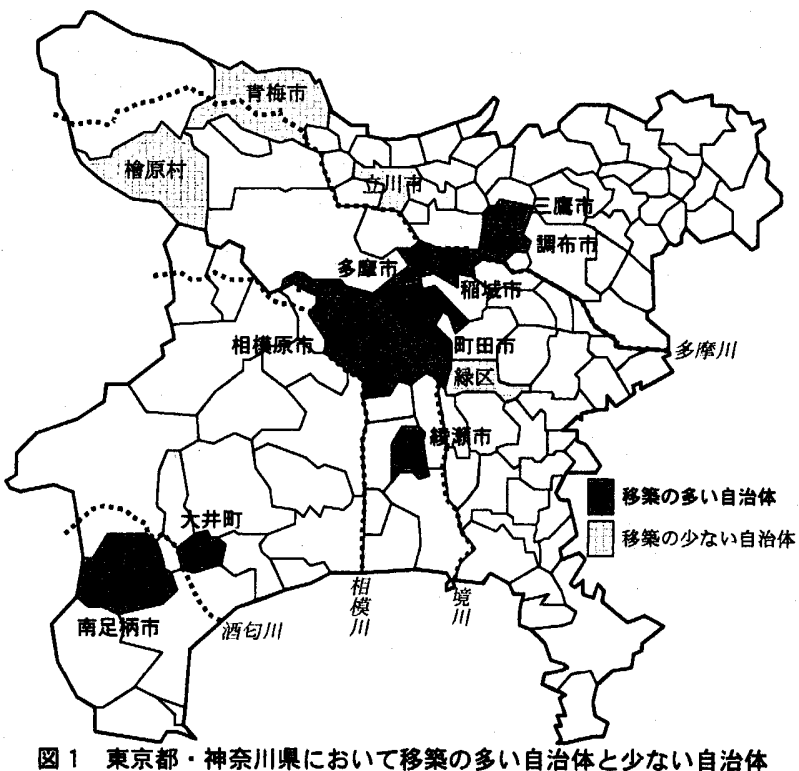

されぬ場合がある23。このように見ると、民俗系の調查である東 京都狛江市、国分寺市、府中市、神奈川県大磯町、二宮町などで 移築棟数の割合が少ないのはその影響と考えることもできよう。

また、藤沢市の民家調查では該当地域が “関東大震災の被害が 顕著であったため《中略》調査対象民家の建築年代の下限を大正 末年” 24 としているが、隣接地域では関東大震災の家屋倒壊を契 機とした民家の移築も複数報告されている25ことから、ここでは そのような対象化が、周辺に比べて極端に少ない移築民家の割合 となって表れていると考えることもできよう。

\section{5 瓷料としての信頼性と時系列に関する考察}

さて、以上のように当該地域では 284 棟の移築民家か確認さ れたが、これらが資料として信頼に足るものであるのかを確認し ておきたい。

本稿で利用した報告書等は 244 册に及ぶため記述内容も多様 で、観察記録の水淮も一定とは言えない。そこで、報告書等にお いて移築記述の根拋か判明する 262 棟について、その根拠を信 頼度が高いと考えられる順に、(1)文書記録で明確なもの（以下、

「文書類」之略す。(2)以下の各括弧内も同様。、(2)㬰際の建物に 移筑痕跡などが確認される (痕跡)、(3)移築を記憶している人が いる、もしくは確度の高い言い伝えがある (聞取)、(4)移築の伝 承がある (伝承)、の順に分類し、表 2 にまとめた ${ }^{26}$ 。その結果、 (1)文書類、(2)痕跡、(3)聞取の分類に 169 棟、65\%、約 $2 / 3$ の 資料が含まれ、こられの資料は信頼に足ると考えた。

また、移築民家の時系列における大まかな分布を把握しておき たい。当該地域における 284 棟の移築民家の内 217 棟について 移築時期が半明するが、これを各世紀前後 50 年ごとに分けて表 3に示した ${ }^{27}$ 。これによると 20 世紀前半が約半数の 104 棟で、 216 棟に対して $48 \%$ 、次いで 19 世紀後半が 90 棟で $41 \%$ 、 この 100 年で移築時期が明かなものの $89 \%$ を占める。ところが 記録が最も残り易い 20 世紀後半は 8 棟、4\%に過ぎないのは、 特に戦後、移筑数が激减したことを数量的に示すものと言えよう。 それでは、19 世紀前半以前において移築件数の少なことはどの ように考えればよいであろうか。 
表 2 移策民家の纪述根提

\begin{tabular}{|c|c|c|c|c|c|c|}
\hline & (1)文徐類 & (2)痕跨 & (3)的取 & (4)伝敢 & 合㖕 & \\
\hline 实数 [樯］ & 9 & 33 & 127 & 93 & 262 & \\
\hline 百分芉 [\%] & 3.44 & 12.60 & 48.47 & 35.50 & 100 & \\
\hline \multicolumn{7}{|c|}{ 表3 移築民家の移築時期 } \\
\hline & 18C後半 & 19C前半 & 19C後半 & 20C前半 & 20C後半 & 合計 \\
\hline 实数 [植] & 1 & 14 & 90 & 104 & 8 & 217 \\
\hline 百分雲 [\%] & 0.46 & 6.45 & 41.47 & 47.93 & 3.69 & 100 \\
\hline
\end{tabular}

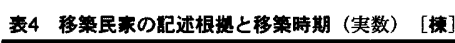

\begin{tabular}{|c|c|c|c|c|c|}
\hline 時期】根城 & (1)文畫類 & (2)底跡 & (3)的取 & (4)伝侌 & If \\
\hline 18 C後半 & 0 & 0 & 0 & 1 & 1 \\
\hline 19C前半 & 0 & 3 & 4 & 7 & 14 \\
\hline 19C後半 & 3 & 11 & 35 & 41 & 90 \\
\hline 20C前半 & 4 & 9 & 69 & 22 & 104 \\
\hline 20C後半 & 0 & 0 & 7 & 1 & 8 \\
\hline 時期不明 & 2 & 10 & 12 & 21 & 45 \\
\hline 站 & $\overline{99}$ & $\overline{33}$ & 127 & 93 & 262 \\
\hline
\end{tabular}

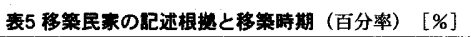

\begin{tabular}{|c|c|c|c|c|c|}
\hline 時期 \根掦 & (1)文衰類 & (2)退跡 & (3)触取 & (4)云竟 & it \\
\hline 18C後半 & 0.00 & 0.00 & 0.00 & 100.00 & 100 \\
\hline 19C前半 & 0.00 & 21.43 & 28.57 & 50.00 & 100 \\
\hline 19C後半 & 3.33 & 12.22 & 38.89 & 45.56 & 100 \\
\hline $20 C_{\text {前 }}$ & 3.85 & 8.65 & 66.35 & 21.15 & 100 \\
\hline 20C後半 & 0.00 & 0.00 & 87.50 & 12.50 & 100 \\
\hline 時期不明 & 4.44 & 22.22 & 26.67 & 46.67 & 100 \\
\hline it & 3.44 & 12.60 & 48.47 & 35.50 & 100 \\
\hline
\end{tabular}

そこで、時系列と移築の根拠を交差させて比較したものが表 4 で、それを百分率で示したものが表 5 である。これによると 18 世紀後半における 1 棟の移築記述根抛は(4)伝承で、19 世紀前半 でも 14 棟中 $50 \%$ に当たる 7 棟が移築記述の根拠を(4)伝承とし、 その割合は高い。19 世紀後半においては(3)聞取の割合が増加す るものの、(4)伝承の割合が高い。以後の時期では(3)聞取の割合が 多くなると見なすことができ、全体としては(1)文献類と(2)痕跡の 割合はどの時代も概して低い。

つまり以上のことから、移築は(1)文献類、(2)痕跡など確実な記 録には残りづらく、多くが(聞取などの方法で伝わるが、時代を 経るごとにそれが(4)伝承となり、遂には(4)伝承そのものが伝わら くなるという傾向を読み取ることができよう。併せて記録の残り づらい理由の一端は既に指摘したように、移築に新築的な意義が 多分に込められることも要因の 1 つで 、以上が 18 世紀以前に 遡る移築の報告件数が極端に少ない理由と言えよう。

\section{6 地域間における移築民家楝数の差異}

さて、前述した宮本の引用は、その直後は以下のように続く。 ただしこれは水田地帯の農家の話で、畑作地の方はそういう

（移築を受けた : 著者注）家はすくなかった。29

確かに、青梅市、立川市（砂川）など、稲作が比較的少ない地 域は極めて低い移築の割合を示す。しかし、同じ条件の綾瀬市、 相模原市、座間市など台地が広い面積を占め、畑作も多い地域に おいてもかなりの数に達する移築棟数を見ることができ、必ずし も全域に対してあてはまるものとはなっていない。

そこで 20 棟以上の調査棟数がある自治体で、移筑民家の割合 が平均值 $13 \%$ の 1.5 倍、19.5\%を上回るものを「移勧の多い」 自治体、13\%の半分、 $6.5 \%$ 下回るものを「移築の少ない」自 治体として図示したものが図 1 である。移築の多い自治体に東京 都では稲城市、多摩市、調布市、町田市、三鷹市、神奈川県では 大井町、綾瀬市、相模原市、南足柄市が挙げられる。逆に移築が 少ない自治体は東京都の青梅市、狛江市、立川市、檜原村、神奈 川県の大磯町、二宮町、藤沢市、横浜市緑区である。

全体的な傾向を見ると、移築の多い自治体である稲城市、多摩 市、調布市、三鷹市は隣接しあい、稲城市 ${ }^{30}$ 、多摩市、調布市は 多摩川の中流域に面している。町田市、綾瀬市 ${ }^{31}$ 、相模原市も近 接し、町田市は境川、相模原市は相模川の流域、大井町、南足柄 市は同じ酒匂川に臨むことが指摘できよう。

一方、前述の民俗系調査を除くと移築民家の割合が少ないのは、 東京都では青梅市、立川市（砂川）、檜原村、神奈川県では横浜 市緑区となる。青梅市は一部、檜原村は大部分が関東山地に位置 し、立川市（砂川）は台地上、横浜市緑区は丘陵地に位置する。

\section{7 さいごに}

以上より、東京都、神奈川県全域における農家民家の移築に ついては以下のようにまとめることができる。

1）地域間ではやや偏りはあるが、各地域で 1 割程度の移築民家 は存在し、全体では少なくとも $13 \%$ 、約 8 棟に 1 棟は移築を受 けた民家と認められる。

2）移築を受けた民家の割合が多いのは多摩川、相模川、境川、 酒匂川など中規模程度以上の河川中流域で、山地や台地、丘陵地 において割合がやや低い。なお、畑作地帯で移築民家が少ないと は限らない。

\footnotetext{
参考文献（自治体名の 50 音順。各行政区域内では年代順。） - 全域的なもの (東京、神奈川に関わるもの)
}

A-1) 石原害治: 日本農民建築 第六輯 (中部 II 、関東 I )、昭和 48(1973).7 A-2)山本勝已ほか : 関東地方の民家、明玄書房、昭和 46(1971).12 A-3,4)民家研究会編集、復刻民家（全 2巻）、柏書房、昭和 61(1986).7 A-5～7) 日本民俗建築学会編: 民俗建築 (全 3巻) 柏書房、昭和 61(1986).11 A-8 16)日本民俗建築学会編 : 民俗建築〈復刻版〉4 12 巻、柏書房、 平成 11(1999).7

A-17)代表研究者富山博日本民家調查研究文献総覧、平成 6 (1994).1 $\mathrm{A}-18$ )東京都教育委員会、神奈川県教育委員会編集 : 日本民家調査報告書 集成 6 関東地方の民家 3 東京 神奈川、平成 10(1998).5、東洋畫林 A-19)奈良国立文化財研究所建造物研究室編集 - 発行 : 都道府県指定文化 財建造物目録、平成 13(2001).3

- 東京都全域およひ広域的なもの（原則として複数自治体に関わる） $\mathrm{T}-1$ ) 東京都教育委員会 : 東京都文化財調查報告書 4 小河内文化財総合調 查報告第 1 分冊、昭和 32 (1957). 3

$\mathrm{T}-2$ )東京都教育委員会 : 東京都文化財調查報告書 6 伊豆諸島文化財総合 調查報告 第 1 分冊、昭和 33(1958). 3

T-3)東京都教育委員会 : 東京都文化財調查報告書 7 伊豆諸島文化財総合 調查報告第 2 分冊、昭和 $34(1959) .3$

T-4)東京都教育委員会 : 東京都文化財調查報告書 8 伊豆諸島文化財総合 調査報告 第 3 分冊 八丈島・青ヶ島の文化財 1 、昭和 35(1958). 3

$\mathrm{T}-5$ )東京都教育委員会 : 東京都文化財調查報告書 10 南多摩文化財総合 調查報告第 1 分冊 多摩丘陵の文化財、昭和 36(1961).3

T-6)東京都教育委員会 : 東京都文化財調查報告書 12 南多摩文化財総合 調査報告第 3 分冊 浅川流域の文化財、昭和 37(1962).3

T-7)東京都教育委員会 : 東京都文化財調查報告書 13 荏原地区文化財総 合調查報告、昭和 38(1963).3

$\mathrm{T}-8$ )東京都教育委員会: 東京都文化財調查報告書 15 北多摩文化財総合 調查報告第 1 分冊 北多摩南部の文化財、昭和 40(1965).3

T-9)東京都教育委員会 : 東京都文化財調查報告書 17 東京都民俗資料緊 急調查報告、昭和 41(1966). 3

$\mathrm{T}-10)$ 東京都教育委員会 : 東京都文化財調查報告書 18 北多摩文化財総 合調查報告第 2 分冊 北多摩北部の文化財、昭和 41(1966). 3

T-11) 東京都教育委員会 : 東京都文化財調査報告書 19 西多摩文化財総 合調查報告第 1 分冊 西多摩北東部の文化財、昭和 42(1967). 3

T-12)東京都教育委員会 : 東京都文化財調查報告書 20 西多摩文化財総 合調查報告第 2 分冊 奥多摩の文化財、昭和 43(1968). 3

$\mathrm{T}-13$ ) 東京都教育委員会 : 東京都文化財調查報告書 23 北東低地帯文化 財総合調查報告 第1 分冊 葛西の文化財、昭和 45(1970). 3 $\mathrm{T}-14$ )東京都教育委員会 : 東京都文化財調査報告書 25 北西区部文化財 
総合調査報告、昭和 47(1972). 3

T-15 22)果京都教育庁生涯学習部文化課発行 : 東京の民俗 $1 \sim 8$ 、昭和 59(1984).3 平成 $4(1992) .3$

T-23)社団法人日本建築学会編:総覧日本の建築 3 東京、昭和 62(1987).8、 新建築社

T-24)大島暁雄ほか編：日本民俗調査報告書集成 関東の民俗 東京都編、 平成 6 (1994) .11、三一書房

$\mathrm{T}-25)$ 大島一人 : 見学できる保存民家、多摩のあゆみ 89、62 73 頁、財 団法人たましん地域文化財団、平成 10 （1998）.2

\section{- 東京都区部}

T-26)板橋区教育委員会事務局社会教育課編集 : 文化財シリーズ 31 い たばしの古民家、昭和 55(1980).3

T-27)板橋区史編さん調查会編集 : 板橋区史資料編 5 民俗、平成 9(1997).3 T-28)板橋区郷土資料館：「いたばし」と古民家（一）板橋区郷土資料 館解説シート、発行年不詳

T-29)江戸川区発行 : 江戸川区史第三巻、昭和 51(1976).3

T-30）(株) 文化財工学研究所編集 : 東京都指定一之江名主屋敷主屋・長 屋門・藏修理工事報告書、平成 5 (1993) .3

T-31)大田区教育委員会発行 : 大田区の民家 大田区の文化財 16、昭和 55(1980). 3

T-32)大田区史編さん委員会編集:大田区史. 資料編;民俗、昭和58(1983).8 $\mathrm{T}-33)$ 北区教育委員会社会教育課編集発行 : 北区の歴史的建造物 文化財 研究紀要 4、平成 2 (1990) .3

$\mathrm{T}-34,35)$ 北区史編箱調查会編集 : 北区史民俗編 1 ,3、平成 4(1992).10、 平成 8(1996).3

T-36)江東区教育委員会編集発行：江東区の文化財 3、平成 3（1991）.4 T-37)新宿区立新宿歴史博物館 : 福室家住宅調查報告書、平成 5 (1993) .3 T-38)杉並区役所 : 杉並区史、昭和 30(1955).3

T-39)杉並区役所 : 新修杉並区史下、昭和 57(1982).10

T-40)杉並区教育委員会編集兼発行 : 杉並の民家その 1 旧篠㥓家住宅 昭和 50(1975).3

T-41)杉並区教育委員会編集兼発行 : 杉並の民家その 2 井口家の長屋門、 昭和 50(1975).3

T-42)世田谷区文化財調查委員会編集 : 世田谷の古民家、昭和 52(1977).3 T-43 45)世田谷区教育委員会文化財係編集・発行 : 世田谷の民家 1 3、 昭和 57(1982).3 昭和 59(1984).3

$\mathrm{T}-46)$ 株式会社安田工務店編集兼発行者: 世田谷代官屋敷修理工事報告書、 昭和 42(1967).5

$\mathrm{T}-47)$ 世田谷区教育委員会発行 : 重要文化財大場家住宅調查報告書、昭和 60(1985). 3

T-48)世田谷区教育委員会編集・発行 : 莲つた古民家、昭和 56(1981).9 T一49)東京都教育委員会: 中央区佃島地区文化財調査報告、昭和 59(1984). 1

T-50)練馬区教育委員会編集兼発行:練馬の民家と屋敷林、昭和 51(1976).3 $\mathrm{T}-51$ )練馬区教育委員会編集兼発行 : 旧名主役宅長谷川家住宅調查報告書、 昭和 58(1983).3

\section{- 東京都多磨地区}

T-52）（株）白井裕泰空間文化研究所編集 : 昭島の民家、平成 13(2001).3 T-53）(株）白井裕泰空間文化研究所編集：あきる野市指定有形文化財旧 市倉家住宅移築復原工事報告書、平成 $12(2000) .12$

$\mathrm{T}-54$ )稲城市文化財調查委員会編集 : 稲城市文化財調查報告書第 1 集（埋 蔵文化財・民家)、「稲城市の民家について」 1 7頁、昭和 54(1979).3 $\mathrm{T}-55$ )稲城市教育委員会生涯学習部社会教育課編集・発行 : 稲城市文化財 調查報告書第 16 集 稲城市の民家建築、平成 11(1999).3

T-56)青梅市郷土博物館発行 : 青梅市の民家、昭和 51(1976).3

T-57)財団法人文化財建造物保存技術協会編集 : 重要文化財旧宮崎家住宅 保存修理工事報告書、昭和 54(1979).8

T-58)東京都教育委員会 : 青梅市御岳神社御師集落文化財調查報告、昭和 61(1986). 3

T-59)国立市教育委員会発行 : 国立市文化財調査報告第2 民家建築、昭 和 46(1971). 5

T-60)国立市史編さん委員会編集 : 国立市史上巻、昭和 63(1988).3 $\mathrm{T}-61$ )国立市教育委員会社会教育課発行 : 国立市文化財調查報告書 34 国 立市古民家復元の足跡一国立市指定文化財・旧柳澤家住宅一、平成 4(1992). 3
T-62) 小金井市誌編さん委員会編集：小金井市誌 II 歴史編、昭和 45(1970). 10

$\mathrm{T}-63$ )国分寺市教育委員会市史編さん室編集 ・発行 : 国分寺市の民家、平 成 8(1996). 1

T-64)小平町誌編纂委員会編集 : 小平町誌、昭和 34(1959).3

T-65)小平市教育委員会発行 : 小平ふるさと村 市指定有形文化財旧神山 家住宅主屋・旧鈴木家住宅穀櫃移築復元修理工事の記録、平成 4(1992).3 T-66)小平市教育委員会発行 : 小平ふるさと村 市指定有形文化財旧小平 小川郵便局舎移築復元修理工事の記録、平成 5(1993).3

$\mathrm{T}-67$ 狛江市教育委員会発行 : 狛江市の民家 狛江市文化財調查報告書 4、 昭和 58(1983). 3

T-68)立川市教育委員会編集・発行 : 砂川の民家 I 、昭和 58(1983).3

T-69)多摩市教育委員会発行:多摩市文化財調查資料民家編、昭和54(1979). 1

T-70)多摩市史編集委員会編集 : 多摩市史叢書(9)多摩市の民俗(衣・食・ 住)、平成 6(1994).3

T-71)調布市教育委員会・調布市郷土館発行 : 調布の古民家、昭和 59(1984).3

T-72)調布市史編集委員会編集 : 調布市史民俗編、昭和 63(1988).3

$\mathrm{T}-73$ ) 東京都教育庁生涯学習部文化課発行 : 西多摩郡日の出町大久野志茂 家書院調査報告書、平成 4(1992). 3

T-74)田中進 : 山の古民家、多摩のあゆみ 89、43〜 54 頁、財団法人たま 乙九地域文化財団、平成 10(1998).2

T-75)瑞穗町史編さん委員会編集 : 瑞穗町史、昭和 49(1974). 4

T-76)田無市史編さん委員会編集 : 田無市史、平成 6(1994).1

T-77)八王子市史編さん委員会編集 : 八王子市史下巻、昭和 42(1967).3

$\mathrm{T}-78$ )都郷土資料小泉家家屋修理委員会編集兼発行者 : 都郷土資料小泉家 家屋修理工事報告書、昭和 50(1975).3

T-79)羽村町史編さん委員会編集 : 羽村町史、昭和 49(1974).5

$\mathrm{T}-80$ )羽村町教育委員会編集之発行 : 羽村町史史料集 10 旧下田家住宅調 查報告書、昭和 58(1983). 1

T-81)東久留米市教育委員会文化課編集 : 東久留米市文化財資料集 (5) 民家編、昭和 52(1977). 3

T-82)東村山市史編纂委員会: 東村山市史史料集(第 1 集)、昭和 41(1966).4 T-83)東村山市史編篓委員会: 東村山市史史料集 (第 2 集)、昭和 42(1967).4 T-84)東村山市史編算委員会編集 : 東村山市史、昭和 46(1971).10

$\mathrm{T}-85)$ 田村善次郎・テム研究所編集 : 旧宮鍋作造家住宅解体調查報告書、 昭和 62(1987).3

T-86)日野市史編さん委員会 : 日野市史民俗編、昭和 58(1983).10

$\mathrm{T}-87)$ 山崎弘編集 : 日野市の古民家、平成 12(2000).3

T-88)府中市史編さん委員会編集 : 府中市史近代編資料集 1 -府中市の現 存草惪民家調查集一、昭和 44(1969). 10

T-89)府中市郷土の森編集 : 府中市郷土の森復原建築物報告集第二集 府 中市重宝旧河内家住宅移築修理工事報告書、昭和 63(1988).3

$\mathrm{T}-90)$ 府中市郷土の森編集 : 展示解説シート No.14 旧越智家住宅、平成 元(1989). 3

T-91)福生市教育委員会編集発行 : 福生市文化財総合調查報告 福生の民 俗 人生儀礼 民家、昭和 51 (1976) .3

T-92)福生市教育委員会発行 : 福生市文化財総合調查報告書 16 福生市の 民俗、昭和 60(1985).3

T-93)山崎弘 : 福生市に残る三棟の民家について、福生市郷土史料室年報 VII、福生市教育委員会・福生市郷土資料室、昭和 63(1988).3 T-94)福生市史編さん委員会編集 : 福生市史資料編、平成元 (1989) .6 T-95)福生市史編さん委員会編集 : 福生市史上巻、平成 5 (1993).6 $\mathrm{T}-96)$ 山崎弘 : 森田芳郎家住宅調查、福生市郷土史料室年報 14、福生市 教育委員会、平成 7 (1995). 3

T-97)町田市史編算委員会発行 : 町田の近世建築、昭和 51(1976).3 T-98)町田市教育委員会発行 : 東京都重宝旧永井家住宅・旧荻野家住宅修 理工事報告書、昭和 52(1977).3

$\mathrm{T}-99$ )東京都教育庁生涯学習部文化課編集発行 : 町田市小野路地区文化財 調查報告 (下)、平成 5(1993).3

T-100)小林昌人 : 幕末漢方医の家 町田市・旧荻野家住宅、多摩のあゆ み 89、36〜42 頁、財団法人たましん地域文化財団、平成 10 (1998）.2 T-101〜103)加倉井昭夫編集 : 三鷹の民家 文化財シリーズ 5,7,9、昭和 54(1979).3 昭和 56(1981).4 
$\mathrm{T}-104)$ 財団法人文化財建造物保存技術協会編集:江戸東京たてもの園 吉 野家住宅移築工事報告書、平成 6(1994).3

T-105)村山町史編纂委員会編集 : 村山町史、昭和 43(1968).3

T-106)片岡雅子 : 村山の民家、武蔵村山市史調查報告 2、武藏村山の民 俗その 1、220〜229 頁、平成8（1996）.3

T-107)片岡雅子 : 村山の民家一村山に残る伝統民家の実例一、武藏村山 市史調查報告 4、武蔵村山の民俗その 2、323 357 頁、平成 9 (1997) .3 $\mathrm{T}-108)$ 片岡雅子 : 村山の民家一建て替えた場合の事例を中心として一、 武藏村山市史調査報告 8、武藏村山の民俗その $4 、 342 \sim 364$ 頁、平成 11

(1999) 3

\section{- 東京都島舆地区}

T-109)東京都教育庁発行 : 文化財の保護 14 「小笠原諸島の建築、昭和 57(1982). 3

T-110)大島町史編さん委員会編集 : 大島町史民俗編、平成 11(1999).3

T-111)利島村編集発行 : 利島村史通史編，平成 8(1996).3

T-112)新島村発行編集 : 新島村史通史編、平成 8(1996).3

T-113)式根島開島百年を記念する会編集 : 式根島開島百年史、昭和 62(1987).5

T-114)東京都教育委員会:八丈島末古地区文化財調查報告、昭和 56(1981). 3

T-115)東京都教育庁社会教育部文化課編集 - 発行 : 御蔵島民俗資料緊急 調查報告、昭和 50(1975).3

\section{・神奈川细全域および広域的なもの}

$\mathrm{K}-1$ ) 社団法人神奈川県建築士会発行 : 神奈川県建築史図説、昭和 37(1962).2

$\mathrm{K}-2 \sim 18$ )神奈川県立博物館編集兼発行: 神奈川県民俗調査報告書 $1 \sim 17$ 、 昭和 43(1968).3 平成元(1989). 3

$\mathrm{K}-19$ )神奈川県教育庁指道部文化財保護課企画 ・編集 : 神奈川県文化財図 鑑建造物篇、昭和 46(1971).3

$\mathrm{K}-20,21$ )神奈川県教育庁指導部文化財保讙課編集 : 足柄地区民俗資料調 查報告書（Ｉ），(II)、昭和 47(1972).3～昭和 48(1973).3

$\mathrm{K}-22$ )神奈川県教育宁指導部文化財保護䂺編集 : 中地区民俗資料調查報告 書、昭和 49(1974).3

K-23)神奈川県教育委員会文化財保護課 : 神奈川県の民家一 足柄地方、 昭和 49(1974). 3

K-24)神奈川県発行 : 神奈川県史各論編 5 民俗、昭和 52(1977).3

$\mathrm{K}-25)$ 神奈川県教育庁社会教育部・文化財保護課企画・編集 : 神奈川県文 化財図鑑補遺篇、昭和 62(1987).3

K-26,27)神奈川県教育委員会文化財保護課発行 : 神奈川県近世民家調查 野帳集（上），(下）、平成元(1989). 3

$\mathrm{K}-28)$ 大島暁雄ほ力編集 : 日本民俗調査報告書集成 関東の民俗 神奈川 県編、三一書房、平成 6(1994).11

\section{- 神奈川県下各市町村}

K-29)川崎市発行 : 神奈川県指定重要文化財旧岩澤家住宅移築修理工事報 告書、平成 $2(1990) .3$

K-30)大井町発行 : 大井町史別編民俗、平成 11(1999).3

$\mathrm{K}-31$ )山北町編集発行 : 大井町史別編民俗、平成 13(2001).3

K-32～34)厚木市古民家調查委員会編集 : 厚木の民家 $1 \sim 3$ 厚木市文化 財調查報告書 19 21、昭和 51(1976).10、昭和 53(1978). 3、昭和 54(1979).3

K-35～41)綾瀬市発行 : 綾瀬市史民俗調查報告書 1～7、平成 3(1991).3 ～平成 11(1999). 3

$\mathrm{K}-42$ )綾瀬市編集発行 : 綾瀬市史 8 （下）別編民俗、平成 13(2001).3 $\mathrm{K}-43$ )伊勢原市教育委員会発行 : 伊勢原市文化財調查報告書 13 古民家、 昭和 49(1974).3

K-44 47)伊勢原市発行 : 伊勢原市史民俗調查報告書 1～4 伊勢原の民 俗、昭和 63(1988).1 平成 3(1991). 3

K-48)伊勢原市発行 : 伊勢原市史別編民俗、平成 9(1997).3

$\mathrm{K}-49$ )海老名市編集発行 : 海老名市史 9 別編民俗、平成 5 (1993) .3

$\mathrm{K}-50$ )重要文化財童宝寺旧石井家住宅修理委員会編集兼発行 : 重要文化財 童宝寺旧石井家住宅修理工事報告書、昭和 45(1970).9

K-51)神奈川県指定重要文化財旧内海家住宅修理工事委員会編集 : 神奈川 県指定重要文化財旧内海家住宅移築修理工事報告書、昭和 56(1981).3 $\mathrm{K}-52)$ 鎌倉市史編さん委員会編さん：鎌倉市史近世通史編、平成 2
(1990) .3

K-53)鈴木嘉吉 : 川崎市内の古民家について ししまどをもつた民家、川 崎市文化財調查集録 1、62 84 頁、昭和 40 (1960). 11

$\mathrm{K}-54$ )川崎市教育委員会編集兼発行 : 重要文化財伊藤家住宅 (川崎市金程) 移築修理工事報告書、昭和 41(1966). 3

K-55)川崎市教育委員会編集兼発行 : 旧清宮家住宅移築修理工事報告書、 昭和 42(1967). 3

K-56)小林昌人 : 川崎市内の民家と民俗、川崎市文化財調查集録 3、59 72 頁、昭和 42(1967).12

K-57)川崎市教育委員会社会教育課文化係編集 : 川崎市文化財調查報告 $\mathbb{V}$ 川崎市最西部地区民俗総合調查、昭和 46(1969). 8

$\mathrm{K}-58)$ 小林昌人 : 多摩丘陵における典型的な一農家、川崎市文化財調查集 録 7、55 63 頁、昭和 47(1972).3

$\mathrm{K}-59)$ 岡上民俗文化財緊急調査団編集 : 川崎市民俗文化財緊急調査報告書 1、岡上の民俗、昭和 57(1982).3

$\mathrm{K}-60)$ 川崎市民俗文化財緊急調查団編集 : 川崎市民俗文化財緊急調查報告 書 4、稲田の民俗、昭和 60(1985).3

K-61)小林昌人: 川崎市内の長屋門、川崎市文化財調查集録 $21 、 147 \sim 163$ 頁、昭和 60(1985). 12

K-62)川崎市民俗文化財緊急調査団編集 : 川崎市民俗文化財緊急調查報告

書 5、小倉の民俗、昭和 61(1986).3

K-63)小林昌人 : 川崎の民家、平成 3(1991).3

$\mathrm{K}-64)$ 関口欣也 ・大野敏 : 川崎市高津区久本岡家住宅調查について、川崎 市文化財調查集録 31、16 25 頁、平成 8(1996).3

$K-65)$ 相模原市民家調査会 : 相模原の民家、昭和 61(1986).3

$\mathrm{K}-66$ )相模原市教育委員会編集 - 発行 : 幕末の和洋折哀三階建て住宅一中

村家住宅一 相模原市文化財調查報告書、平成 13(2001).3

$\mathrm{K}-67)$ 相模原市立博物館編集発行: 相模原市民俗調查報告書 大岛 -上矢 部・田名・上溝・当麻地区の民俗、平成 14(2002).3

$\mathrm{K}-68)$ 清水擴執筆 : 座間市の古民家、昭和 54(1979).3

$\mathrm{K}-69)$ 逗子市教育委員会編集・発行 : 逗子市文化財調查報告書第八集 昭 和 54(1979). 3

$\mathrm{K}-70)$ 逗子市教育委員会編集・発行 : 逗子市文化財調查報告書第 10 集 民 俗、昭和 56(1981).3

K-71)逗子市発行 : 逗子市史別編 I 民俗編、昭和 62(1987).3

$\mathrm{K}-72$ ) 茅ヶ崎市教育委員会発行: 茅ヶ崎市文化財資料集 9 、昭和 58(1983). 3

K-73)茅ヶ崎市教育委員会編集発行 : 茅ヶ崎市指定重要文化財旧和田家住 宅移築復原工事報告書、昭和 60(1985).3

K-74)城山町編集発行 : 城山町史 4資料編民俗、昭和 63(1988).3

$\mathrm{K}-75$ )神奈川県教育委員会 : 神奈川県における近世民家の変遷 I 藤野町 牧野、昭和 33(1958).8

K-76)藤野町教育委員会発行 : 藤野町の古民家、昭和 55(1980).3

$\mathrm{K}-77 \sim 81)$ 大磯町編集 - 発行 : 大磯町史民俗調查報告書 1 5、平成 5(1993).3 平成 10(1998).3

$\mathrm{K}-82$ )二宮町教育委員会発行 : 二宮町文化財調査報告書 25 二宮町民俗 調查報告書、平成 $9(1997) .3$

K-83)川崎市編集兼発行 : 重要文化財旧北村家住宅移築修理工事報告書、 昭和 43(1968).3

$\mathrm{K}-84$ )神奈川県教育委員会 : 神奈川県における近世民家の変遷 II 秦野の 民家、昭和 38(1963).3

K-85)秦野市発行 : 秦野市史別巻民俗編、昭和 62(1987).9

$\mathrm{K}-86$ )秦野市教育委員会社会教育課編集 : 秦野のすまい (1) - 農家編一、

平成4（1992）.3

K-87)清水撗 : 平塚市の古民家、自然と文化 平塚市博物館資料 8、53 75 頁、昭和 52(1977). 12

$\mathrm{K}-88$ )平塚市博物館編集 : 平塚市須賀の民俗 平塚市博物館資料 17、昭 和 54(1979). 3

K-89 93)平塚市市史編さん課編集 : 平塚市史民俗調查報告書 2 6、昭 和 57(1982).3 昭和 62(1982).3

K-94)小林梅次: 藤沢の民家、わが住む里 20、72 79 頁、昭和 44(1969).3 K-95)小林梅次 : 藤沢の住居と民俗、藤沢市文化財調查報告書 20、53 68 頁、昭和 60(1985). 3

K-96)藤沢文庫刊行会編集 : 藤沢史跡めぐり、昭和 60(1985).4

K-97)藤沢市史編さん委員会編集 : 藤沢市史 7 文化遺産・民俗編、昭和 
$55(1980) .10$

K-98)藤沢市教育委員会編集・発行、藤沢の民家、平成 5（1993）.3 K-99)藤沢市教育委員会生涯学習課博物館潐備担当編集 - 発行 : 民家解体 保存調查報告書 (その一)、平成 13(2001).3

$\mathrm{K}-100$ ) 藤沢市教育委員会生涯学習課博物館淮備担当編集 - 発行 : 民家解 体保存調查報告書 (その二)、平成 14(2002).3

K-101)大和市教育委員会編集 : 大和市文化財調査報告書 7 上和田 $\cdot$ 下 和田の民俗、昭和 56 (1981) .3

$\mathrm{K}-102)$ 大和市教育委員会編集 : 大和市文化財調查報告書 8 深見 $\cdot$ 上草 柳・下草柳の民俗、昭和 57 (1982) .9

$\mathrm{K}-103)$ 大和市教育委員会編集: 大和市文化財調查報告書 11 大和の民家、 昭和 57 (1982) .9

K-104)大和市教育委員会編集 : 大和市文化財調查報告書 13 下鶴間・福 田の民俗、昭和 58 （1983）.3

$\mathrm{K}-105)$ 吉田純一 : 大和市の民家と盖峑、大和市史研究 10、33〜50 頁、 昭和 59(1984). 3

K-106)大和市教育委員会編集 : 大和市文化財調查報告書 18 大和市の民 俗総括編、昭和 60 (1985).1

$\mathrm{K}-107)$ 吉田純一 : 明治期の上草柳村と集落、大和市史研究 $11 、 40 \sim 53$ 頁、昭和 60(1985).3

K-108)大和市教育委員会編集 : 大和市文化財調查報告書 19 上和田の旧 小川家住宅 解体調查編、昭和 62(1987).3

$\mathrm{K}-109)$ 大和市教育委員会編集 : 大和市文化財調査報告書 23 下和田の旧 関水家住宅 、昭和 62(1987).3

$\mathrm{K}-110)$ 大和市教育委員会編集 : 大和市文化財調査報告書 29 下鶴間の旧 北島家住宅 解体調查編、昭和 63(1988).3

$\mathrm{K}-111$ )大和市教育委員会編集 : 大和市文化財調査報告書 44 上和田の旧 白井家住宅 、平成 3(1991).3

$\mathrm{K}-112)$ 大和市教育委員会編集 : 大和市文化財調查報告書 52 上和田の旧 渡辺家住宅 、平成 3(1991).3

$\mathrm{K}-113)$ 大和市教育委員会社会教育部社会教育課編集 : 大和市文化財調查 報告書 51 大和の民家 2、平成 4（1992）.3

K-114)大和市教育委員会社会教育課編集 : 大和市文化財調査報告書 54 深見の旧富澤家住宅、平成 5（1993）.3

K-115)大和市教育委員会社会教育部社会教育課編集 : 大和市文化財調查 報告書 62 市重文旧小川家住宅・旧北島家住宅移築復原工事報告書本文 編、平成 7 (1995) .3

$\mathrm{K}-116)$ 津田良樹 - 大和市教育委員会社会教育課文化財保護担当編集 : 大 和市文化財調査報告書 67 下鶴間の旧小倉家住宅主屋 解体調查編、平 成 10 (1998) .10

$\mathrm{K}-117)$ 横浜市教育委員会編集発行 : 港北二ュータウン地域内文化財調查 報告 民家、昭和 46 年度、昭和 $47(1972) .3$

K-118 124)横浜市計画局発行 : 港北二ュータウン地域内歴史民俗調查 報告＼cjkstart昭和 49 55 年度、昭和 50(1975).3 昭和 58(1983).3

K-125）(財) 文化財建造物保存技術協会編集 : 旧内野家住宅移築修理工 事報告書、昭和 55(1980).10

$\mathrm{K}-126)$ 横浜市市民局市民活動部広報課広報センタ一編集・発行 : 市民グ ラフヨコハマ 34 、昭和 $55(1980) .10$

$\mathrm{K}-127)$ 横浜市文化財総合調查会横溝家文化財総合調査団編集 : 横溝家文 化財総合調查報告書一鶴見区獅子ヶ谷一、昭和 60(1985).3

K-128）(財）文化財建造物保存技術協会編集 : 重要文化財関家住宅表門 修理工事報告書、昭和 60(1985). 9

$\mathrm{K}-129)$ 港北二ュータウン郷土誌編纂委員会編集 ・発行 : 都筑の民俗、平 成元(1989).5

\section{注記}

${ }^{1}$ 宮沢智士 : 富山県一農家 (佐伯家) の明和年間の家作とその文書、日本 建築学会論文集 193、p.p.69～73、昭和 47(1972). 3。

2 草野和夫: 東北民家史研究、中央公論美術出版、53 58 頁、平成 3(1995).4、 及び 草野和夫 : 近世民家の成立過程、中央公論美術出版、180～183 頁、 平成 7(1995). 2 。

3 御船達雄、山崎弘、平山: 古家移築とその住宅観について一東京都稲城 市民家調查の一事例加一－民俗建築 109、26～33 頁、平成 8(1996).5。

4 例えば参考文献 $\mathrm{K}-61$ 。

5 参考文献 T-88、188 頁。
6 参考文献 $\mathrm{T}-55$ 参照。なお、 6 棟の内 5 棟は移築を受けたもの、 1 棟は 主屋の新築に際して旧主屋を現市域内に移築したもの。

7 参考文献T-88、187 頁、T-90、1 頁。

8 参考文献 $\mathrm{T}-71 、 21$ 頁。

9 参考文献 T $-1 、 100$ 頁。なお、この後続けられた一連の調査はいずれも この方針に則って調査対象の住宅が選定された。

10 文化庁監修: 国宝·重要文化財大全 12 建造物(下巻)、毎日新聞社、平 成 12(2000). 3、の分類と記載などによった。

11 参考文献 K-26、1 頁に“近世民家の状態を把握するには全県的に組織 的調查を行う必要がある”との指摘がある。

12 建築基淮法第 2 条参照。

13 注 10 に準じた。

14 一連の調查は参考文献 T-1 8、10〜14などとして報告書が発刊され た。これに後の調査成果である参考文献 T-49,58,109 などを加え参考文 献A-18か汗行された。本稿ではこれらを都による報告書として用いた。 15 以下本稿では各区市町村が発刊した区市町村史、区市町村誌を総称す る場合は「市史類」の語を用いる。

16 基本的には所有者により重複の校定を行つたが、代替わり等で所有者 名の代わる場合等があり、次いで住所、図面、写真等により校定を行った。 17 参考文献A-18、1 頁、宮澤智士：日本民家研究の礎「民家緊急調查報 告書」復刻の意義、にその事情が記される。

18 参考文献 $\mathrm{K}-23,75,84$ 。

19 参考文献 $\mathrm{K}-26,27$ 。

20 基本的に東京都と同様、所有者名、住所、図面、写真等により校定し た。なお、大磯町、秦野市の参考文献 $\mathrm{K}-79 \sim 81 、 \mathrm{~K}-86$ では所有者名が アルファベット等で記載され、住所も字名までの記載に留まるため、字及 ひ図面、写真で校定を行った。

21 例えば神奈川県大和市富沢美晴家住宅主屋は、参考文献 K-103 に移築 の指摘はないが、後の参考文献 $\mathrm{K}-114 、 8$ 頁には移築の指摘がある。ま た、神奈川県逗子市石渡賢一家住宅主屋は、参考文献 $\mathrm{K}-26$ では移筑の指 摘がないものの、参考文献 $\mathrm{K}-69 、 27$ 頁には関係文書も含め、移築につ いての論及がある。このように今回用いた参考文献の中にも新筮・移築の 確認に至っていない場合もあると考えることができ、少なくともこの数量 が確認されるとの立場を採った。

22 参考文献 T- 88 。

23 例えば参考文献 T-15、「緊急民俗文化財分布調查要項」の「実施要領 によれば、“調査内容は大正年間当時を基本と”するもので (1 頁)、「調 查票記入要領」「二 項目別の記入要項「住」の欄（2頁）に建築年代、 移築の有無などの項目は見られない。但し、「調查票記入要領」「一 各項 目共通事項」には“各調查票の裏面の概要欄には、全般的な説明、変遷 (話 者の知っている限り古くから現在に至る）などを書く”とはあるが、この 調査において対象住居の建築年代等に言及するものは極めて少ない。

${ }^{24} \mathrm{~K}-98 、 10$ 頁、「調查の概要」の「1 調査主旨」

25 参考文献 K-43、31 頁の伊勢原市米山幸造家住宅、 K-49、292 頁の海 老名市赤井賞家住宅などの例を挙げることができる。

${ }^{26}$ 分類が複数区分に重複する場合はより上位の区分に分類した。なお、 百分率の合計は四捨五入のため、計算が 100 にならない場合がある。以 下、表3、表 5 も同様。

27 「何年前」とする場合は、報告書等の調査年から遡つた。また、「何代 前」とする場合は、 1 代を 25 年に換算して報告書等の調查年から遡った。 なお、江戸時代後期は 19 世紀前期、江戸時代末期は 19 世紀後期、明治 時代は 20 世紀前期に含めた。

28 注 3 参照。

29 参考文献 T-88、188 頁。

30 参考文献 T- $55 、 92$ 96 頁にある稲城市川崎家住宅では多摩川を通じ て材を運び 上流の青梅市と類似する民家を見ることができる。また，注 1 の宮澤による富山県佐伯家の例でも、移築の部材を小矢部川によって移 動させている。川们多築を介した例として見なすことができよう。

31 綾瀬市で多数の移築が報告されたのは、厚木飛行場建設により多くの 民家が移転を余儀なくされたという事情が大きい。参考文献 $\mathrm{K}-41$ 参照。

（2004年10月 10 日原稿受理， 2005 年 3 月 3 日採用決定） 